\title{
HETEROCHROMATIN PATTERNS AND KARYOTYPE RELATIONSHIPS WITHIN AND BETWEEN THE GENERA Brycon AND Salminus (PISCES, CHARACIDAE)
}

\author{
Vladimir Pavan Margarido ${ }^{1}$ and Pedro Manoel Galetti Junior ${ }^{2}$
}

\begin{abstract}
Chromosomes of two Brycon species (B. Iundii and B. microlepis) and Salminus hilarii were analyzed. Based on constitutive heterochromatin distribution patterns, karyotypic relationships within and between Bryconinae and Salmininae were examined. A monophyletic origin for the genus Brycon, comprising at least two chromosome synapomorphies (presence of two large submetacentric bearing paracentromeric and telomeric heterochromatin), is suggested. Moreover, Bryconinae and Salmininae may represent a monophyletic unit among Characidae, as they share several chromosome features.
\end{abstract}

\section{INTRODUCTION}

Characidae, the largest family among the Characiformes, includes nearly $55 \%$ of the fishes belonging to this freshwater fish order (Fink and Fink, 1981), and may not assemble a monophyletic group of species (Lucena, 1993). The genus Brycon has about 40 species (Howes, 1982), and together with Triportheus and Chalceus, had been included in the tribe Bryconini (Weitzman, 1960). Currently, Brycon appears alone in the subfamily Bryconinae (Gery, 1977), and has been considered more closely related to Triportheus and Salminus than other South American characids (Uj, 1990; Portugal, 1990).

Previous chromosome studies on Brycon species from various hydrographic basins revealed significant karyotype stability, characterized by the same chromosome number $(2 \mathrm{n}=50)$ and great similarity in chromosome structure among species. Nucleolar organizer region (NOR) sites also appear to be conserved within this genus, and a common chromosome pair has been detected carrying these sites in all species thus far studied (Almeida-Toledo et al., 1996; Margarido and Galetti Jr., 1996). In contrast, changes in constitutive heterochromatin seem to have an important role in the chromosome evolution of these fishes, and two major patterns of heterochromatin distribution have been reported for this genus (Margarido and Galetti Jr., 1996). First, a group consisting of $B$. lundii, B. brevicauda and $B$. insignis was characterized by predominantly paracentromeric $\mathrm{C}$ bands, mainly in the submetacentric chromosomes. Another group, comprising Brycon sp., B. orbignyanus, $B$. microlepis and B. cephalus, was characterized by telomeric bands in some metacentric chromosomes.

In the present study, representative species of both

\footnotetext{
${ }^{1}$ Departamento de Ciências Biológicas, Universidade Estadual do Oeste do Paraná, Rua Universitária, 2069. 85814-110 Cascavel, PR, Brasil.

${ }^{2}$ Departamento de Genética e Evolução, Universidade Federal de São Carlos, Via Washington Luís, Km 235, 13565-905 São Carlos, SP, Brasil. Send correspondence to V.P.M. E-mail: galettip@power.ufscar.br
}

heterochromatin major patterns were reanalyzed through $\mathrm{C}$ banding and base-specific fluorochrome mithramycin and DAPI staining (new data). Chromosomes of Salminus hilarii were also analyzed and a phylogenetic relationship between Bryconinae and Salmininae is discussed.

\section{MATERIAL AND METHODS}

Mitotic chromosomes obtained from anterior kidney cells (Bertollo et al., 1978; Fenocchio et al., 1991) of Brycon lundii (5 females and 5 males) from the São Francisco River (Três Marias, MG) and Brycon microlepis (7 females and 3 males) from the Cuiabá River (Cuiabá, MT), as well as Bryconinae and Salminus hilarii (Salmininae, 5 females and 3 males) from the Mogi-Guaçu River (Pirassununga, SP), were analyzed using $\mathrm{C}$ banding (Sumner, 1972) and fluorescent staining with mithramycin A (MM) and 4'6-diamidin-2-phenylindole (DAPI) and counterstained with distamycin A (DA) (Schweizer, 1976; Schmid, 1980).

\section{RESULTS}

Brycon species studied here presented less heterochromatin than S. hilarii. B. microlepis showed pale C bands in centromeric regions of most chromosomes. Dark heterochromatic blocks appeared to be equilocally distributed in the paracentromeric region of both arms of the first metacentric (M) pair, apparently in the entire short arm and telomeres of the long arm of the second $\mathrm{M}$ pair, and in the telomeres of the long arm of the third M pair. Darkly stained heterochromatic blocks were also detected on the long arm, near the centromere of the two largest submetacentric (SM) (11 and 12) and three other SM pairs $(13,16$, 22) (Figure 1A).

Equilocal dark $\mathrm{C}$ bands could also be observed in the paracentromeric region of both arms of the first $\mathrm{M}$ pair in B. lundii. Paracentromeric dark $\mathrm{C}$ bands were also observed in at least two M pairs $(2,6)$ and eight SM pairs 


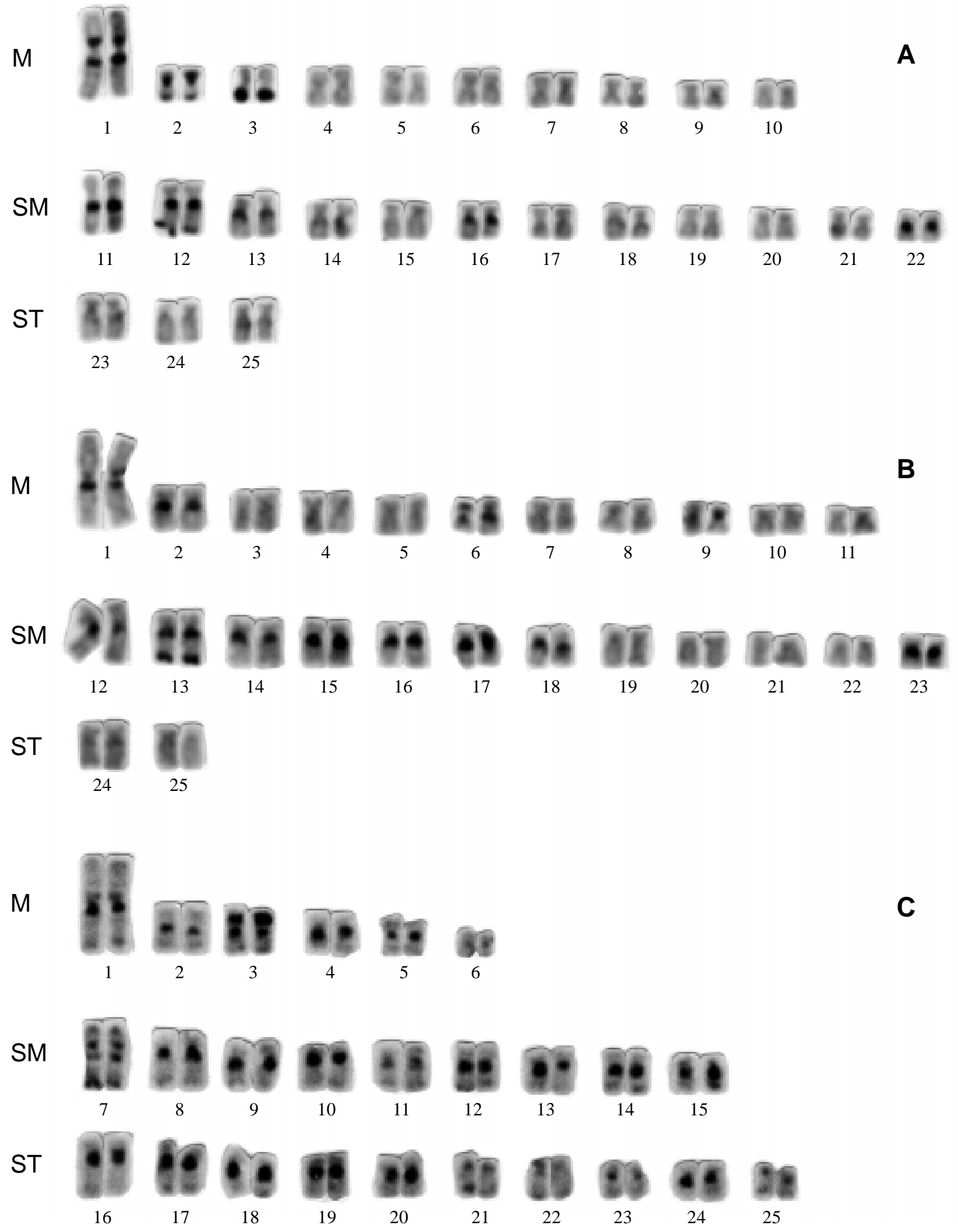

Figure 1 - C banding karyotypes of (A) Brycon microlepis, (B) Brycon lundii and (C) Salminus hilarii. 
$(12,13,14,15,16,17,18,23)$. In one of these (13), dark C bands were detected in the telomeres of its long arm (Figure 1B). Larger amounts of heterochromatin could be observed in $S$. hilarii, with paracentromeric dark $\mathrm{C}$ bands in most chromosomes of the complement. Like Bryconinae species, the largest $\mathrm{M}$ pair also showed equilocal paracentromeric heterochromatic blocks on both chromosome arms. A large SM pair showed a particular $\mathrm{C}$ banding pattern with a pale $\mathrm{C}$ band on the telomere of the short arm, a conspicuous centromeric heterochromatic block, a proximal dot-like $\mathrm{C}$ band on the long arm, and dark $\mathrm{C}$ bands on its telomeres (Figure 1C).
Mithramycin staining revealed two fluorescent $\mathrm{MM}^{+}$bands in the chromosome complement of $B$. lundii (Figure 2A), located in the telomeric region of the long arm of the second SM pair. DAPI staining showed no differential fluorescence among these chromosomes (Figure 2B). Similar results were obtained in B. microlepis (Figure $2 \mathrm{C}, \mathrm{D})$.

\section{DISCUSSION}

The karyotypic macrostructure observed in Brycon is quite similar to the chromosome complement of $S$. hilarii
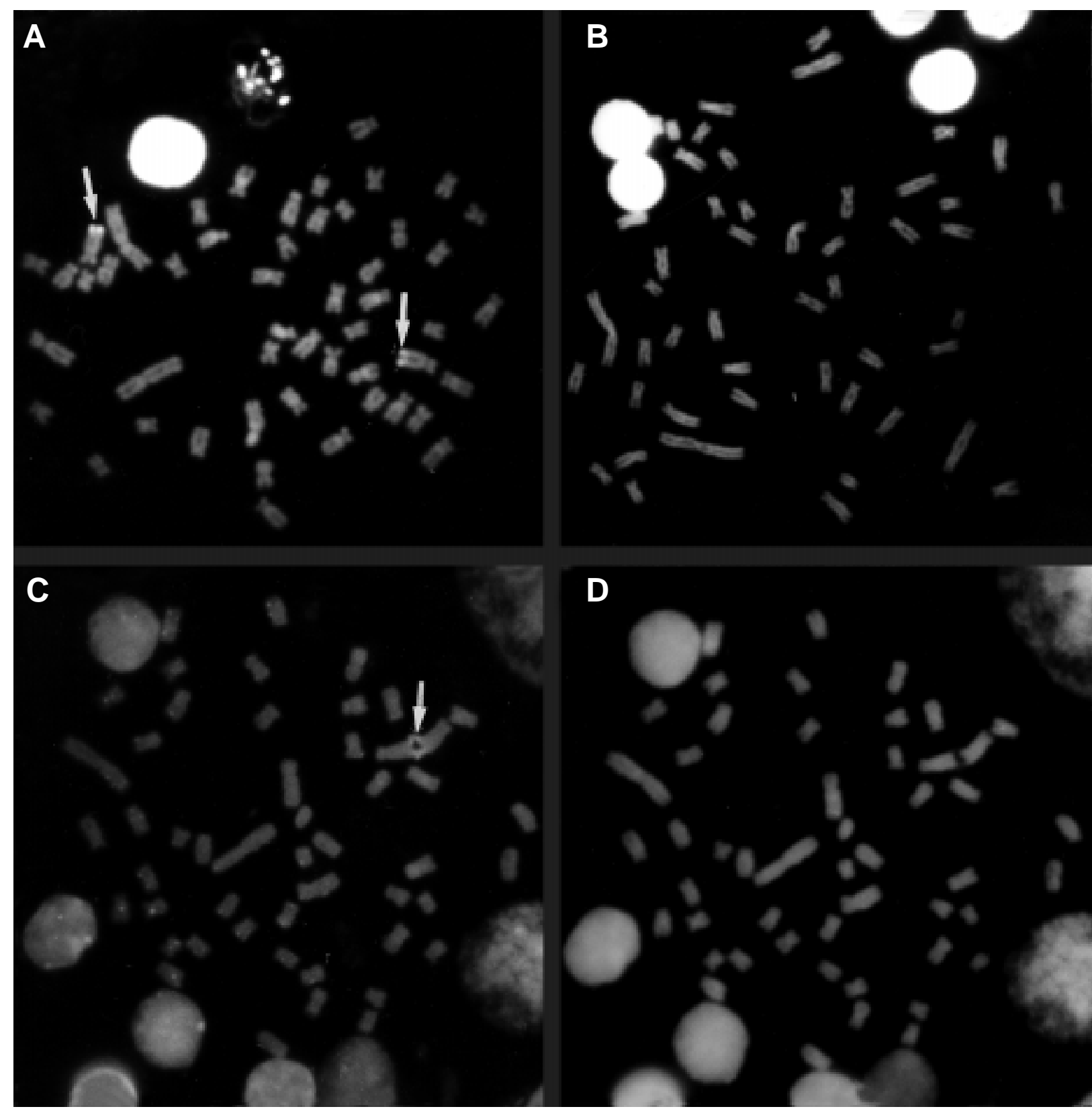

D

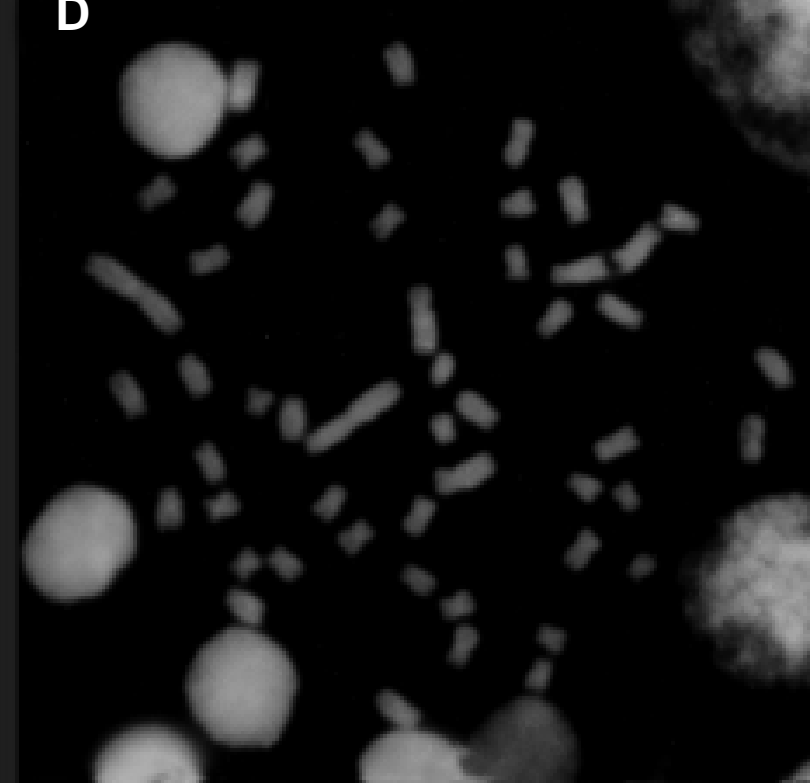

Figure 2 - Metaphases stained by mithramycin in (A) Brycon lundii and (C) Brycon microlepis, and by DAPI in (B) Brycon lundii and (D) Brycon microlepis. Mithramycin positive bands are indicated by arrows. 
(Marco, 1986; present study) and other Salminus species (S. maxillosus and S. brasiliensis) studied through Giemsa and silver staining (Marco, 1986). This strongly suggests that this karyotype pattern may be ancestral for some Characidae. Although some Tetragonopterinae (e.g. Astyanax), Acestrorhynchinae and Cynopotaminae have $2 \mathrm{n}=50$, they show a karyotype structure divergent from Bryconinae and Salmininae, bearing several uniarmed chromosomes. Most groups currently defined in the family Characidae show a different karyotype pattern than the one apparently shared by Brycon and Salminus. Chalceus (Chalcidiinae), for instance, shows $2 \mathrm{n}=52-54$ (Muramoto et al., 1968; Ojima et al., 1976). Triportheus (Triportheinae) also shows $2 \mathrm{n}=52$ and cytologycally differentiated sex chromosomes (Falcão et al., 1985; Bertollo and Cavallaro, 1992).

$\mathrm{C}$ banding shows significant differences within and between the genera Brycon and Salminus. Diverse heterochromatin patterns have already been reported within the genus Brycon (Margarido and Galetti Jr., 1996), and were confirmed in the present paper. Heterochromatin appears reduced to approximately 11 chromosome pairs in the karyotype of $B$. lundii, and no more than 8 pairs in $B$. microlepis. In contrast, large paracentromeric heterochromatins are abundant in the karyotype of $S$. hilarii. The two largest submetacentric pairs, which showed similar C banding between $B$. lundii and B. microlepis, have been reported as very conservative among Brycon species (Margarido and Galetti Jr., 1996). These chromosomes seem to be modified in the C-banded karyotype of S. hilarii and could characterize a synapomorphy in the genus Brycon. A large metacentric pair bearing a typical equilocal paracentromeric heterochromatin in both chromosome arms, as observed here in Brycon species and S. hilarii, has been reported in other characids (Scheel, 1973; DanielSilva, 1996) and may represent a synapomorphy for the family.

Silver staining detected a large submetacentric pair bearing the nucleolar organizer region in the telomeres of its long arm in both genera. In Brycon these chromosomes present $\mathrm{C}$ bands restricted to both paracentromeric and telomeric regions of the long arm, while in $S$. hilarii the first appears modified to a proximal dot-like $\mathrm{C}$ band, suggesting a divergence related to heterochromatin along the NOR-bearing chromosomes between both genera.

DAPI staining showed no differential fluorescence among the chromosome complement of $B$. lundii and $B$. microlepis, and mithramycin staining revealed only two bright $\mathrm{MM}^{+}$bands along their karyotypes. As, in general, reported for fishes (e.g. Mayr et al., 1985), these $\mathrm{MM}^{+}$ bands appear coincident to AgNOR sites and also to $\mathrm{C}$ banded heterochromatin of both Brycon species. S. hilarii similarly showed only two $\mathrm{MM}^{+}$bands/cell, corresponding to AgNORs (data not shown), and again indicates a common pattern of chromosome evolution among these fish groups.
In conclusion, chromosome data strongly suggest that Bryconinae and Salmininae may form a monophyletic unit among characids, and heterochromatin may have an important role in their karyotype diversification.

\section{ACKNOWLEDGMENTS}

This research was supported by Universidade Federal de São Carlos (UFSCar), Conselho Nacional de Desenvolvimento Científico e Tecnológico (CNPq) and Coordenação de Aperfeiçoamento de Pessoal de Nível Superior (CAPES). The authors thank Companhia do Vale do Rio São Francisco (CODEVASF) for help during fish collection. Publication supported by FAPESP.

\section{RESUMO}

Foram analisados os cromossomos de duas espécies de peixes do gênero Brycon (B. lundii e B. microlepis) e de Salminus hilarii. Principalmente baseado no padrão de distribuição da heterocromatina constitutiva, foram discutidas as relações cariotípicas dentro e entre os grupos Bryconinae e Salmininae. É sugerida uma origem monofilética para o gênero Brycon, com pelo menos duas sinapomorfias cromossômicas (presença de dois grandes submetacêntricos apresentando blocos pericentromérico e telomérico de heterocromatina constitutiva). Ainda, Bryconinae e Salmininae, compartilhando vários caracteres cromossômicos, podem formar uma unidade monofilética entre os Characidae, na qual outros caracídeos não estão incluídos.

\section{REFERENCES}

Almeida-Toledo, L.F., Bigoni, A.P., Bernardino, G., Foresti, F. and Toledo-Filho, S.A. (1996). Karyotype and NOR conservatism with heterochromatin reorganization in Neotropical Bryconids. Caryologia 49: $35-43$.

Bertollo, L.A.C. and Cavallaro, Z.I. (1992). A highly differentiated ZZ/ ZW sex chromosome system in a Characidae fish, Triportheus guentheri. Cytogenet. Cell. Genet. 60: 60-63.

Bertollo, L.A.C., Takahashi, C.S. and Moreira Filho, O. (1978). Cytotaxonomic considerations on Hoplias lacerdae (Pisces, Erythrinidae). Rev. Bras. Genét. I: 103-120.

Daniel-Silva, M.F.Z. (1996). Estudos citogenéticos comparativos em quatro espécies do gênero Astyanax (Pisces, Characidae). Master's thesis, Instituto de Biociências, Universidade de São Paulo, São Paulo.

Falcão, J.N., Cruz, L.A. and Feldberg, E. (1985). Cromossomos sexuais ZZ/ZW em Triportheus (Characidae) da Amazônia. Cienc. Cult. 38: 858 (Abstract).

Fenocchio, A.S., Venere, P.C., Cesar, A.C.G., Dias, A.L. and Bertollo, L.A.C. (1991). Short term culture from solid tissues of fishes. Caryologia 44: 161-166.

Fink, S.V. and Fink, W.L. (1981). Interrelationships of the ostariophysan fishes (Teleostei). Zool. J. Linn. Soc. Lond. 72: 297-353.

Gery, J. (1977). Characoids of the World. T.F.H. Publications, Neptune City, NY

Howes, G. (1982). Review of the genus Brycon (Teleostei, Characoidei). Bull. Br. Mus. (Nat. Hist.) Zool. 43: 1-47.

Lucena, C.A.S. (1993). Estudo filogenético da família Characidae com uma discussão dos grupos naturais propostos (Teleostei, Osthariophysi, Characiformes). Doctoral thesis, Instituto de Biociências, Universidade de São Paulo, São Paulo.

Marco, D.A. (1986). Estudos cromossômicos em peixes da subfamília Salmininae (Pisces, Characidae). Master's thesis, Departamento de Ciências Biológicas, Universidade Federal de São Carlos, São Carlos. 
Margarido, V.P. and Galetti Jr., P.M. (1996). Chromosome studies in fish of the genus Brycon (Characiformes, Characidae, Bryconinae). Cytobios 85: 219-228.

Mayr, B., Rab, B. and Kalat, M. (1985). Localisation of NORs and counterstain-enhanced fluorescence studies in Perca fluviatilis (Pisces, Percidae). Genetica 67: 51-56.

Muramoto, J., Ohno, S. and Atkin, N.B. (1968). On the diploid stage of the fish order Ostariophysi. Chromosoma 24: 59-66.

Ojima, Y., Ueno, K. and Hayashi, M. (1976). A review of chromosome numbers in fish. La Kromosomo 2: 19-47.

Portugal, L.P.S. (1990). Revisão sistemática do gênero Triportheus cope (Teleostei, Characiformes, Characidae). Master's thesis, Instituto de Biociências, Universidade de São Paulo, São Paulo.

Scheel, J.J. (1973). Fish chromosomes and their evolution. Internal Report of Danmarks Akvarium. Charlottenlund, Denmark.
Schmid, M. (1980). Chromosome banding in Amphibia: IV. Differentiation of GC- and AT-rich chromosome regions in Anura. Chromosoma 77: 83-103.

Schweizer, D. (1976). Reverse fluorescent chromosome banding with chromomycin and DAPI. Chromosoma 58: 307-324.

Sumner, A.T. (1972). A simple technique for demonstrating centromeric heterocromatin. Exp. Cell Res. 75: 304-306.

Uj, A. (1990). Etude comparative de l'osteologie cranienne des poissons de la famille des Characidae et son importance phylogenetique. Doctoral thesis, Faculté des Sciences de l'Université de Genève, Genève

Weitzman, S.H. (1960). The phylogenetic relationships of Triportheus, a genus of South American Characid fishes. Stanford Ichthyol. Bull. 7: 239-243.

(Received January 23, 1998) 
